\title{
PEMANFAATAN LKM DAN ANIMASI JAVA LABORATORY SEBAGAI MEDIA PEMBELAJARAN FISIKA PADA MATAKULIAH FISIKA KUANTUM UNTUK MENINGKATKAN AKTIVITAS BELAJAR MAHASISWA PROGRAM STUDI PENDIDIKAN FISIKA FPMIPA IKIP PGRI MADIUN
}

\author{
Mislan Sasono \\ Program Studi Pendidikan Fisika, FPMIPA IKIP PGRI Madiun \\ Jalan Setia Budi No. 85 Madiun Telp. (0351 )462986, Fax. (0351) 459400 \\ Email: mislan_fis03@yahoo.com
}

\begin{abstract}
ABSTRAK
Penelitian ini bertujuan mengetahui apakah pemanfaatan LKM dan animasi java laboratory pada matakuliah fisika kuantum dapat meningkatkan aktivitas mahasiswa dalam pembelajaran. Perangkat pembelajaran tersebut diimplikasikan oleh dosen model pada matakuliah fisika kuantum dan dengan terpenuhinya tujuan tersebut diharapkan aktivitas belajar mahasiswa meningkat dengan menggunakan media LKM dan animasi java laboratory sebagai media pembelajaran.

Penelitian ini termasuk ke dalam penelitian tindakan kelas. Pemanfaatan media LKM dan animasi java laboratory dilaksanakan tiga kali siklus pembelajaran yaitu siklus I, II, dan III. Dengan subjek penelitian yaitu mahasiswa semester VI tahun akademik 2011/2012 pada semester genap. Untuk data pengamatan dilakukan menggunakan lembar observasi pengelolaan pembelajaran dosen dan aktivitas mahasiswa serta hasil belajar siswa selama pembelajaran dicatat sebagai data kuantitatif dan dianalisis secara deskriptif kualitatif.

Berdasarkan hasil penelitian tindakan kelas, dapat disimpulkan bahwa: pemanfaatan LKM dan animasi java laboratory sebagai media pembelajaran fisika pada matakuliah fisika kuantum mampu meningkatkan aktivitas belajar mahasiswa dengan peningkatan respon aktivitas belajar mahasiswa dari siklus I, II, dan III adalah 78,42\%, 79,18\%, 95,83\%.
\end{abstract}

Kata Kunci: Media, LKM, Aktivitas Belajar Siswa

\section{PENDAHULUAN}

Proses belajar siswa maupun mahasiswa perlu adanya motivasi yang dapat dijadikan pendorong terhadap daya serap siswa dan mahasiswa, sebab siswa dan mahasiswa diharapkan dapat menyerap materi pelajaran yang telah diprogramkan dalam kurikulum, agar dapat meningkatkan hasil belajar. Dari hasil belajar, guru maupun dosen dapat mengetahui kedudukan siswa dan mahasiswa yang pandai, sedang, atau kurang. Hal ini dirasa penting oleh karena rendahnya hasil siswa dan mahasiswa dapat disebabkan oleh berbagai hal, antara lain ketidakpuasan terhadap hasil yang diperoleh dan kurangnya rangsangan baik dari dalam diri siswa maupun dari luar siswa mahasiswa. Dengan demikian pelajaran apapun yang diberikan oleh guru dan dosen, hendaknya guru maupun dosen memotivasi siswa dan mahasiswanya dalam belajar yang efektif. Media Lembar Kegiatan Mahasiswa (LKM) dapat digunakan untuk meningkatkan efektifitas belajar siswa dan mahasiswa.

Kerumitan bahan yang akan disampaikan kepada siswa maupun mahasiswa dapat disederhanakan dengan bantuan media. Media dapat mewakili apa yang kurang mampu guru ucapkan melalui kata-kata atau kalimat tertentu.

Media adalah suatu pembelajaran yang digunakan dalam rangka lebih mengekfetifkan 
komunikasi dan interaksi antara guru dan siswa ataupun dosen dengan mahasiswa dalam proses pendidikan dan pengajaran di sekolah atau dikampus (Oemar Hamalik 2003:23). Media dan alat yang sering dipakai dalam proses belajar mengajar diantaranya adalah Lembar Kegiatan Mahasiswa, yang selanjutnya disingkat LKM. Yang di maksud LKM adalah Lembar yang berisi pedoman bagi siswaataupun mahasiswa untuk melaksanakan kegiatan/kerja atau tugas yang terprogram.

Ratna Wilis Dahar (1996: 29) mengungkapkan bahwa "Lembar Kegiatan Mahasiswa" (LKM) adalah lembar kerja yang berisikan informasi dan interaksi dari guru kepada siswa ataupun dosen dengan mahasiswanya agar dapat mengerjakan sendiri suatu aktifitas belajar, melalui praktek atau penerapan hasil-hasil belajar untuk mencapai kompetensi dasar.

Dari dua pendapat tersebut dapat disimpulkan bahwa Lembar Kegiatan Mahasiswa (LKM) adalah merupakan salah satu media pembelajaran yakni media cetak dengan tujuan mengaktifkan siswa, memungkinkan siswa dapat belajar sendiri menurut kemampuan dan minatnya merangsang kegiatan belajar dan juga merupakan variasi pengajaran agar siswa tidak menjadi bosan.

Media pembelajaran menurut Heinich seperti yang dikutip oleh Azhar Arsyad (2004 : 3) adalah media yang membawa pesan atau informasi dengan tujuan instruksional atau mengandung maksud-maksud pengajaran. Pada hakekatnya, media sebagai sarana agar manusia dapat memberikan dan menerima informasi melalui panca inderanya. Dalam hal ini media hanya dipandang sebagai alat sehubungan dengan peran media dalam pembelajaran, Gagne dalam Zuhdan (2001) menghubungkannya dengan aspek lain yaitu : 1) Alat panca indera.
2) Saluran komunikasi.

3) Jenis stimulus/rangsangan (suara, bacaan, dan gambaran serta bentuk rangsangan lainnya).

4) Media peralatan fisik (buku, gambar, model, teks berprogram, komputer, slide, tape recoder dll)

Karena itu, media pembelajaran dapat dipandang sebagai perangkat lunak (software) atau alat belajar dan perangkat keras (hardware). Hal ini sesuai dengan pandangan Bretz dalam Zuhdan (2001).

Mata kuliah fisika kuantum, bobot 3 SKS, salah satu mata kuliah keilmuan dan keterampilan (MKK) di Prodi Pendidikan Fisika yang mengalami permasalahan yang cukup serius, baik dalam kualitas proses pembelajaran maupun hasil belajar yang dicapai mahasiswa. Terbukti, dalam dua tahun akademik berturutan, rerata hasil belajar mahasiswa pada mata kuliah ini berkisar antara 2,22 sampai dengan 2,45 pada skala lima.

Sehingga, dapat diinformasikan bahwa terdapat lebih dari 50\% mahasiswa dalam tiap tahun akademiknya tidak berhasil lulus dengan nilai minimal berkategori B. Rendahnya hasil belajar mahasiswa tersebut merupakan indikator rendahnya penguasaan mereka terhadap konsep-konsep mata kuliah fisika kuantum. Jika dibiarkan, hal ini dikhawatirkan akan sangat mempengaruhi kualitas penguasaan mahasiswa dalam materi mata kuliah fisika lanjut, yang memprasyaratkan penguasaan konsep mata kuliah fisika kuantum yang dikenal sebagai 'ilmu dasar' bagi penelaahan gejala dan sifat berbagai sistem mikroskopik (Krane, 1992).

Hasil wawancara dengan mahasiswa yang pernah mengikuti perkuliahan fisika kuantum menunjukkan bahwa hampir $80 \%$ mahasiswa kurang termotivasi untuk mengikuti perkuliahan mata kuliah ini, tetapi mereka 
sangat takut tidak lulus. Mereka menganggap bahwa fisika kuantum merupakan bagian dari mata kuliah yang sulit, materinya kebanyakan bersifat non observable. Mereka menyadari akan pentingnya kualitas penguasaan konsep mata kuliah ini karena sangat membantu untuk dapat mengikuti perkuliahan fisika lanjut. Mereka mengeluhkan tentang dirinya, bahwa mereka dapat mengerti dan memahami materi perkuliahan yang disajikan dosen, tetapi setelah dihadapkan pada permasalahan mengenai materi perkuliahan tersebut lebih-lebih menyangkut penerapannya, mereka tidak mampu memecahkan masalah yang dihadapi tersebut. Ungkapan ini mengindikasikan bahwa hasil belajar mahasiswa pada mata kuliah ini tidak bersifat tahan lama dan berkelanjutan. Akibatnya, mahasiswa tidak mampu menerapkan konsep-konsep yang diperolehnya dalam situasi baru, sehingga pemahaman konsep-konsep materi pada mata kuliah fisika lanjut menjadi kurang yang berimplikasi pula pada rendahnya hasil belajar yang dicapai mahasiswa.

Dari latar belakang dan identifikasi masalah di atas, perlu adanya suatu media yang dapat membantu mengaktifkan dan meningkatkan aktivitas belajar mahasiswa sehingga peneliti bermaksud meneliti bagaimana pemanfaatan media khususnya LKM dan animasi java laboratory dapat meningkatkan aktivitas belajar mahasiswa serta peningkatan pada hasil belajar mahasiswa.

\section{METODE}

Penelitian ini dirancang dalam bentuk Penelitian Tindakan Kelas. Adapun prosedur kegiatan dan desain penelitian tindakan ini mengacu pada pendapat Mc. Taggart (dalam Madya, 1994: 19-23) yang meliputi: (1) kegiatan perencanaan, (2) kegiatan tindakan, (3) observasi, dan (4) refleksi. Penelitian tindakan kelas ini agar tercapai tujuan- tujuannya, maka dilaksanakan dengan proses pengkajian berdaur yang terdiri dari 4 tahap, sebagaimana ditunjukkan pada bagan 1 berikut.

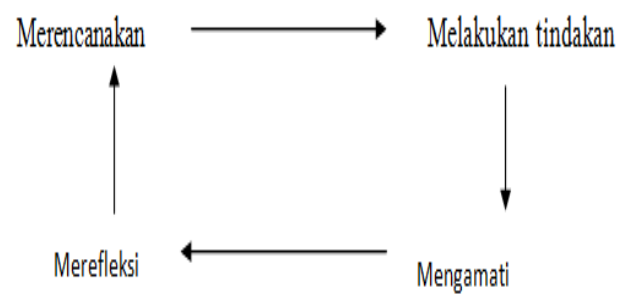

Bagan 1. Alur Penelitian Tindakan Kelas

Pengambilan aktivitas belajar mahasiswa menggunakan media LKM dan animasi java laboratory diperoleh dari lembar observasi aktivitas mahasiswa.

\section{HASIL DAN PEMBAHASAN}

Hasil penelitian diuraikan dalam tahapan berupa siklus-siklus pembelajaran. Dalam penelitian ini kegiatan pembelajaran dilakukan peneliti yang bertindak sebagai dosen, Penelitian tindakan kelas ini dilakukan dalam 3 siklus, setiap siklusnya 3 SKS dengan waktu 120 menit tiap SKS. Dari ketiga siklus yang dilakukan didapatkan untuk aktivitas belajar siswa dari siklus I, II, dan III adalah 78,42\%, $79,18 \%$, 95,83\%. Sehingga dapat kita simpulkan bahwa aktivitas belajar mahasiswa selama pembelajaran berlangsung dengan pemanfaatan media LKM dan animasi java laboratory mengalami peningkatan dari siklus I sampai dengan siklus III.

Berdasarkan observasi dan evaluasi maka hasil penelitian ini dapat dipaparkan sebagai berikut:

1. Siklus I (pertama)

Siklus pertama terdiri dari empat tahap, yakni perencanaan, pelaksanaan, observasi dan refleksi serta planning. Adapun keberhasilan dan kegagalan yang terjadi 
pada siklus I (pertama) adalah sebagai berikut :

a. Skor Aktivitas belajar mahasiswa memperoleh 78,42\%.

Kesimpulam pelaksanaan dan evaluasi dari observer:

1) Kelompok masih terlalu besar

2) Perlunya mengeset alokasi atau strategi waktu dalam rencana pembelajaran

3) Masih terlihat beberapa mahasiswa yang belum siap padahal pembelajaran sudah dimulai

4) Pada saat penanyangan animasi masih banyak yang ngobrol sendiri

Temuan di atas memperlihatkan bahwa perlu adanya informasi terhadap mahasiswa agar pada saat proses pembelajaran dimulai sudah siap, serta belum baiknya desain LKM sehingga memakan waktu dalam pelaksanaan.

2. Siklus II (kedua)

Siklus kedua memiliki tahapan yang yaitu terdiri dari empat tahap, yakni perencanaan, pelaksanaan, observasi dan refleksi serta planning. Adapun keberhasilan dan kegagalan yang terjadi pada siklus II (kedua) adalah sebagai berikut :

a. Skor Aktivitas belajar mahasiswa memperoleh $78,42 \%$ menjadi $79,18 \%$.

Kesimpulam pelaksanaan dan evaluasi dari observer:

1) Kelompok sudah kecil, satu kelompok terdiri dari 3 orang

2) Perlunya mendesain bahasa LKM lebih baik supaya tidak membingungkan

3) Mahasiswa kebingungan dalam mengartikan paket gelombang

4) Perlu memperjelas pada aturan atau sistem pada saat mahasiswa melakukan presentasi
Temuan di atas memperlihatkan bahwa perlu bahasa LKM yang baik supaya tidak ada makna yang bias atau konsitensi, belum terjalinnya diskusi antar kelompok terkait dengan menjawab permasalahan yang ada serta perlu pengesetan posisi duduk agar terbentuk diskusi yang baik.

3. Siklus III (ketiga)

Siklus III (ketiga) juga sama dengan siklus I dan II yaiutu memiliki tahapan yang terdiri dari empat tahap, yakni perencanaan, pelaksanaan, observasi dan refleksi serta planning. Adapun keberhasilan dan kegagalan yang terjadi pada siklus III (ketiga) adalah sebagai berikut :

a. Skor Aktivitas belajar mahasiswa memperoleh 79,18\% menjadi 95,83\%

Kesimpulam pelaksanaan dan evaluasi dari observer:

1) Kelompok sudah kecil, satu kelompok terdiri dari 3 orang, dan tempat duduk dibuat tipe atau model V

2) Perlunya melihat sintak model pembelajaran yang diacu dalam pembelajaran

3) Perlu adanya pengaturan jarak antara kelompok satu dengan yang lainnya

4) Perlu memperjelas pada aturan atau sistem pada saat mahasiswa melakukan presentasi

Temuan di atas memperlihatkan bahwa pembelajaran lebih baiknya tetap melihat sintak pembelajaran yang digunakan agar diskusi lebih tertata dan bisa komunikatif serta tidak membingungkan observer saat mengamati perlu adanya pemisahan jarak satu dengan kelompok lainnya.

Berdasarkan hasil dari siklus I, I, dan III diperoleh pengertian bahwa pemanfatan LKM 
dan animasi java laboratory sebagai media pembelajaran dalam matakuliah fisika kuantum dari ketiga siklus yang dilaksanakan memperihatkan bahwa pemanfatan LKM dan animasi java laboratory dapat meningkatkan aktivitas belajar siswa hal tersebut terlihat dari hasil respons aktivitas siswa.

\section{KESIMPULAN}

Berdasarkan hasil penelitian tindakan kelas, dapat disimpulkan bahwa: pemanfaatan LKM dan animasi java laboratory sebagai media pembelajaran fisika pada matakuliah fisika kuantum mampu meningkatkan aktivitas belajar mahasiswa dengan peningkatan respon aktivitas belajar mahasiswa dari siklus I, II, dan III adalah 78,42\%, 79,18\%, 95,83\%.

\section{DAFTAR RUJUKAN}

Azhar Arsyad. 2004. Media Pembelajaran. Jakarta: Raja Grafindo

Krane, K, 1992. Modern Physics. Singapore: John Wiley \&Sonc, Inc.

Oemar Hamalik. 2003. Proses Belajar Mengajar. Jakarta: PT Bumi Aksara

Ratna Wilis Dahar. 1996. Teori-teori Belajar. Jakarta: Erlangga

Suwarsih Madya. (1994). Panduan Penelitian Tindakan. Seri Metodologi Penelitian. Yogyakarta: Lembaga Penelitian IKIP Yogyakarta.

Zuhdan Kun Prasetyo, dkk. 2001. Kapita Selekta Pembelajaran Fisika. Jakarta: Universitas Terbuka 